\title{
CHARACTERIZATION AND EVALUATION OF TREATABILITY OF WASTEWATER GENERATED IN KHUZESTAN LIVESTOCK SLAUGHTERHOUSES AND ASSESSING OF THEIR WASTEWATER TREATMENT SYSTEMS
}

\author{
FARZADKIA M. ${ }^{1}$ \\ VANANI A.F. ${ }^{2}$ \\ GOLBAZ S., ${ }^{3, *}$ \\ SAJADI H.S. ${ }^{4}$ \\ BAZRAFSHAN E. ${ }^{5}$
}

\author{
${ }^{1}$ Department of Environmental Health Engineering, School of Health \\ Iran University of Medical Sciences, Tehran, Iran \\ ${ }^{2}$ Department of Environmental Protection, Khuzestan, Iran \\ ${ }^{3}$ Department of Environmental Health Engineering, School of Health \\ Tehran university of Medical Sciences, Tehran, Iran \\ ${ }^{4}$ National Institute of Health Research \\ Tehran University of Medical Sciences, Tehran, Iran \\ ${ }^{5}$ Health Promotion Research Center \\ Zahedan University of Medical Sciences, Zahedan, Iran
}

Received: 29/06/2015

Accepted: 23/12/2015

Available online: 11/01/2016 e-mail: golbazs@gmail.com *to whom all correspondence should be addressed:

\section{ABSTRACT}

Slaughterhouse wastewaters are characterized by a high organic content, mainly composed of proteins and fats. Therefore, these wastewaters should be treated efficiently prior to discharge into receiving bodies to avoid severe environmental pollution. This work aimed to characterize slaughterhouse wastewater generated in one province of Iran (Khuzestan), evaluating various suitability of biological treatment, assessing wastewater treatment plants performance and feasibility of wastewater reuse. Composite samples were collected from input and output of wastewater treatment plant during 6 months (spring and summer) and were analyzed for TSS, turbidity, temperature, conductivity, $\mathrm{pH}, \mathrm{COD}, \mathrm{BOD}_{5}$, fat, total coliform and fecal coliform. Data analysis was done using Excel and SPSS software. The results showed that different quantities of wastewater were generated in any slaughterhouses of Ahvaz (120-600 l/sheep/day), Dezful (110-550 l/sheep/day) and Shushtar (139-694 l/sheep/day). Khuzestan slaughterhouses wastewater is classified by pollution severity as strong wastewater. The $\mathrm{BOD}_{5} / \mathrm{COD}$ ranges from 0.3 to 0.5 , which indicates applicability of biological treatment. Wastewater treatment plant of Ahvaz with anaerobic stabilization ponds and extended aeration activated sludge process has the highest removal efficiencies of pollutants. The result also indicated reuse of slaughterhouses effluent was not acceptable due to not comply with the standards of Iran. Finally, if safe use or disposal of these effluents is desired, blood capture from raw wastewater for reducing the amounts of organic loading must be implemented. Also, use of an appropriate treatment plant is noted.

Keywords: Slaughterhouse industry, Meat processing, Wastewater, Reuse

\section{Introduction}

Wastewater from slaughterhouses is a mixture of the processing water from both the slaughtering line and the cleaning of the guts, which causes a large variation in the concentration of organic matter. The main pollutant in slaughterhouse discharges is organic matter. The contributors of organic load to these effluents are paunch, feces, grease, fat and lard, undigested foods, blood, suspended material, urine, loose meat, soluble proteins, excrement, manure, grit and colloidal particles (Ün et al., 2009, Bazrafshan

Farzadkia M., Vanani A.F., Golbaz S., Sajadi H.S. and Bazrafshan E. (2016), Characterization and evaluation of treatability of wastewater generated in Khuzestan livestock slaughterhouses and assessing of their wastewater treatment systems, Global NEST Journal, 18(1), 108-118. 
et al., 2012). The consumed water per slaughtered animal is different according to animal kind and the slaughtering process, and ranges from 1 to $8.3 \mathrm{~m}^{3}$. A major part of this value is discarded as wastewater, with values ranging from 0.4 to $3.1 \mathrm{~m}^{3}$ per slaughtered animal (Gurel and Buyukgungor, 2011, Saddoud and Sayadi, 2007). Metcalf and Eddy, (2003), reported wastewater generation rates can be as high as $80 \%$ of the total consumed water. Reuse of treated wastewater constitutes a perfect alternative in many cases such as agriculture, irrigation, industrial use, replenishment of surface water and groundwater recharge. But lack of health and discharging of mentioned large volume of effluents to receiving water and surrounding environment has been pursued a destructive environmental impact (Kobya et al., 2006). These effluents also causes important environmental problems as a result of organic pollution and microbial loads, and the increasing problems of its removal must be addressed as a result of legislative constraints and the cost of treatment and final disposal. Thus, the pollution potential of meat-processing and slaughterhouse plants is very high. It has been estimated at over one million and three million population equivalent in the Netherlands and France, respectively (Massé and Masse, 2000a). Blood also as one of the most important pollutants in slaughterhouse wastewater, contains $375,000 \mathrm{mg} \mathrm{l}^{-1}$ chemical oxygen demand (COD) (Sarairah and Jamrah, 2010). Massé and Massé (2000a) reported if the blood from a single cow carcass is allowed to discharge directly into a sewer line; the effluent load would be equivalent to the total sewage produced by 50 people on average day. In addition, the wastewater contains high concentration of suspended solid (SS), oil and grease, hair, and non biodegradable materials (Sarairah and Jamrah, 2010). The slaughterhouse wastewater may also have pathogens, including Salmonella and Shigella bacteria, parasite eggs, amoebic cysts, coliforms, fecal coliform, and Streptococcus groups of bacteria (Nafarnda et al., 2012).

Very few studies have been devoted to the characterization of slaughterhouse wastewater. Wastewater of hog slaughterhouses in eastern Canada was characterized by Masse and Masse (2000a). They stated that raw wastewater have high concentration of COD and SS in the range of 2,333 to 8,627 $\mathrm{mg} \mathrm{l}^{-1}$, and 736 and 2,099 $\mathrm{mg} \mathrm{l}^{-1}$, respectively. Sarairah and Jamrah (2010) assessed generated wastewater in Amman slaughterhouse. Their results showed the concentration of COD, BOD ${ }_{5}$ and TSS parameters of the screened samples exceed the maximum allowable limits based on Jordan institute of standards and metrology requirements related to the reuse of reclaimed wastewater for the agricultural purposes. Also many researchers investigated methods of treating slaughterhouse wastewaters by using several treatment technologies such as anaerobic sequencing batch reactor (Massé and Masse, 2001, Masse and Masse, 2005), anaerobic-aerobic fixed-film reactor (Del Pozo and Diez, 2005), up flow anaerobic sludge blanket reactors (Aguilar et al., 2003), coagulation-flocculation treatment (Aguilar et al., 2003) and etc.

To our knowledge, on the national level, no significant studies have been carried out to characterize and investigate the produced wastewater from slaughterhouse industry. As a result, we tried to study in this field at a local level. The objectives of the present study include: (a) assessing the characterization of the generated wastewater in Khuzestan slaughterhouses and evaluating the season changes them, (b) evaluating various suitability of biological treatment, (c) comparison of the generated effluent quality with standards of Iran Environmental Protection Agency (Iran EPA) are shown in Table 1 and feasibility of wastewater reuse, (d) assessing wastewater treatment plants performance in mentioned slaughterhouses, (e) presentation of short guide to improve slaughterhouse wastewater treatment plant (SWWTP) efficiency.

\section{Material and Methods}

\subsection{Description of the study area}

Khuzestan is the largest province in southwest of Iran, with a population of 4,531,720 people and an area of $64,057 \mathrm{~km}^{2}$. The studies have shown that 31 traditional and semi industrial livestock slaughterhouses exist in the province of Khuzestan and livestock slaughterhouses of Ahvaz, Dezful and Shushtar are most famous slaughterhouses of this province. Livestock slaughterhouse of Ahvaz was built on a land of 8 hectares with an approximate area of $8,000 \mathrm{~m}^{2}$ at kilometer 15 of Ahvaz - Khorramshahr and near the 
Karoon River. The wastewater of this slaughterhouse is treated by anaerobic stabilization ponds (as pretreatment) and extended aeration activated sludge process. The Dezful slaughterhouse covers over an area of $8,800 \mathrm{~m}^{2}$ and is located in the city's Dezful. The wastewater of this slaughterhouse is treated by the septic tank and the produced effluent is used to irrigate the surrounding land in the agricultural season. In other seasons the wastewater is discharged into the river. Shushtar slaughterhouse is located within residential fabric of the city around the Gorger River. The wastewater collected from the slaughterhouse after a short period (few hours), without any treatment procedure is discharged into the Gorger River.

\subsection{Methods}

This work is a cross-sectional study. Composite samples of wastewater were collected from the livestock slaughterhouses of Ahvaz, Dezful, and Shushtar. After conducting the field visits, review of the available records and expert meetings with the relevant authorities, and depending on the variation in the kind of slaughterhouses, wastewater treatment methods, and number of slaughtered animal, wastewater sources were selected. The quantity of wastewater in these slaughterhouses was determined by periodic registration of the water amount consumed and average period of the study was obtained. Sampling was carried out over a period of 6 months (spring and summer time). Considering the slaughtering time, the raw wastewater and the effluent were sampled before the first anaerobic stabilization pond and after chlorination pond, respectively in Ahvaz slaughterhouse. While, sampling locations in Dezful slaughterhouse were input and output channels of septic tank. Moreover, a sample was taken monthly from the effluent of the Shushtar slaughterhouse. The samples were stabilized and transferred to the laboratory at $4^{\circ} \mathrm{C}$. Then, samples were analyzed for chemical oxygen demands (COD), biochemical oxygen demands $\left(\mathrm{BOD}_{5}\right)$, total suspended solids (TSS), turbidity, conductivity and fat and also biological characteristics such as total coliform bacteria (TC) and fecal coliform bacteria (FC). The pH and temperature parameters were determined in situ. All of parameters selected for analysis during this study were determined based on previous studies in this field (Manjunath et al., 2000, Del Pozo and Diez, 2005, Caixeta et al., 2002) and all of them were measured in duplicates according to standard methods for the Examination of Water and Wastewater (APHA, 1992). Then, for evaluating the functioning of the WWTP in Ahvaz and septic tank of Dezful, removal efficiency of these pollutants was investigated. In order to evaluate ability of effluent reuse, the results of this study were compared with the standards of Iran. These standards are shown in Table 1.

Table 1. Iranian standards for wastewater discharge to environment and effluent reuse

\begin{tabular}{cccc}
\hline Pollutant & Surface water & Well & Agriculture\& irrigation \\
\hline $\mathrm{pH}$ & $6.5-8.5$ & $5-9$ & $6-8.5$ \\
\hline $\mathrm{BOD}_{5}\left(\mathrm{mgO}_{2} \mathrm{I}^{-1}\right)$ & $30(50)$ & $30(50)$ & 100 \\
\hline $\mathrm{COD}\left(\mathrm{mgO}_{2} \mathrm{l}^{-1}\right)$ & $60(100)$ & $60(100)$ & 200 \\
\hline Turbidity (NTU) & 50 & -- & 50 \\
\hline $\mathrm{TSS}\left(\mathrm{mg} \mathrm{l}^{-1}\right)$ & $40(60)$ & -- & 100 \\
\hline Fat $\left(\mathrm{mg} \mathrm{l}^{-1}\right)$ & 10 & 10 & 10 \\
\hline $\mathrm{TC}(\mathrm{No} . / 100 \mathrm{ml})$ & 1000 & 1000 & 400 \\
\hline $\mathrm{FC}(\mathrm{No} . / 100 \mathrm{ml})$ & 400 & 400 &
\end{tabular}

Abbreviations: $\mathrm{BOD}_{5}$ : biochemical oxygen demands; COD: chemical oxygen demands; TSS: total suspended solids; TC: total coliform bacteria; FC: fecal coliform bacteria.

Data was analyzed using Excel and SPSS software. Lastly, the technical alternatives to correct deficiencies and improve the process of the wastewater treatment system were presented. 


\section{Results and discussion}

\subsection{Characteristics of studied SWWTPS}

The produced wastewater rate of slaughterhouse varies according to the capacity of the slaughtering. This rate was highest in the Ahvaz slaughterhouse and lowest in the Shushtar slaughterhouse (Table 2). Nevertheless, wastewater generation per capita in the slaughterhouse was Shushtar> Ahvaz> Dezful accordingly. Produced wastewater in these slaughterhouses per capita is estimated for each of the slaughtered livestock. Depending on the degree of the automation of the slaughterhouse, kind of slaughtered animal, the health and the cultural differences of the society were significant. The average wastewater production of studied slaughterhouses was $120 \mathrm{I} \mathrm{d}^{-1}$ for each of the animal slaughtered.

Table 2. Characteristics of studied SWWTPS

\begin{tabular}{ccccc}
\hline Slaughterhouse & $\begin{array}{c}\text { Slaughterhouse } \\
\text { capacity }(\mathbf{p e r} \\
\text { sheep) }\end{array}$ & \multicolumn{2}{c}{$\begin{array}{c}\text { Produced wastewater flow } \\
\text { rate }\end{array}$} & In-plant wastewater treatment \\
\cline { 3 - 4 } Ahvaz & 1960 & 235 & 120 & $\begin{array}{c}\text { Anaerobic stabilization ponds and } \\
\text { extended aeration activated sludge } \\
\text { process }\end{array}$ \\
\hline Dezful & 390 & 43 & 101 & Septic tank \\
\hline Shushtar & 180 & 25 & 139 & Without any treatment \\
\hline
\end{tabular}

*Considering that each cow is equivalent to 5 sheep, capacity of the slaughterhouse is expressed as per sheep.

Therefore, amount of produced wastewater in the slaughterhouse was relatively high. This issue should be applied for proper management of the consumption of water and in other words minimizing the wastewater volume in these centers.

\subsection{Characteristics of the raw wastewater}

Three operating WWTPs were selected in the Khuzestan province. One plant had anaerobic stabilization ponds and extended aeration activated sludge process and another plant applied septic tank and the Shushtar slaughterhouse lacks of wastewater treatment plant. Characteristics of each slaughterhouse and its WWTP, containing the applied treatment technology, wastewater flow rate, and capacity of the slaughterhouse per sheep are summarized in Table 2. The amount of produced industrial wastewater in the livestock slaughterhouse of Ahvaz, Dezful and Shushtar is equivalent to 235,43 , and $25 \mathrm{~m}^{3}$ day $^{-1}$ (or 120, 101 and $139 \mathrm{l} /$ sheep/day), respectively.

Table 3. Quality of the influent wastewater for each studied slaughterhouse WWTP

\begin{tabular}{|c|c|c|c|c|c|c|c|c|c|}
\hline Slaughterhouse & \multicolumn{3}{|c|}{ Ahvaz } & \multicolumn{3}{|c|}{ Dezful } & \multicolumn{3}{|c|}{ Shushtar } \\
\hline \multirow{2}{*}{ Parameters } & Spring & Summer & Total & Spring & Summer & Total & Spring & Summer & Total \\
\hline & Ave \pm S.D. & Ave \pm S.D. & Ave \pm S.D. & Ave \pm S.D. & Ave \pm S.D. & Ave \pm S.D. & Ave \pm S.D. & Ave \pm S.D. & Ave \pm S.D. \\
\hline $\mathrm{pH}$ & $7.1 \pm 0.65$ & $6.4 \pm 0.17$ & $6.8 \pm 0.6$ & $6.8 \pm 0.1$ & $6.24 \pm .2$ & $6.7 \pm 0.3$ & $6.36 \pm 0.3$ & $7.9 \pm 0.9$ & $6.9 \pm 0.9$ \\
\hline $\begin{array}{c}\text { TSS } \\
\left(\mathrm{mg} \mathrm{l}^{-1}\right)\end{array}$ & $1964 \pm 62$ & $1564 \pm 403$ & $1764 \pm 339$ & $1831 \pm 45$ & $1897 \pm 29$ & $1864 \pm 50$ & $1435 \pm 14$ & $1526 \pm 415$ & $1481 \pm 244$ \\
\hline $\begin{array}{c}\mathrm{BOD}_{5} \\
\left(\mathrm{mg} \mathrm{l}^{-1}\right)\end{array}$ & $2831 \pm 941$ & $2392 \pm 213$ & $2611 \pm 656$ & $1535 \pm 117$ & $1599 \pm 128$ & $1567 \pm 115$ & $1223 \pm 204$ & $1224 \pm 208$ & $1224 \pm 185$ \\
\hline $\begin{array}{l}\text { TCOD } \\
\left(\mathrm{mg} \mathrm{l}^{-1}\right) \\
\end{array}$ & $4920 \pm 684$ & $4783 \pm 425$ & $4852 \pm 515$ & $4757 \pm 318$ & $4477 \pm 146$ & $4550 \pm 270$ & $3983 \pm 231$ & $3663 \pm 617$ & $3823 \pm 452$ \\
\hline $\mathrm{EC}(\mu \mathrm{s})$ & $4493 \pm 1722$ & $3817 \pm 535$ & $4155 \pm 1199$ & $2938 \pm 198$ & $2966 \pm 23$ & $2960 \pm 129$ & $563 \pm 18$ & $583 \pm 10$ & $572 \pm 16$ \\
\hline Turbidity (NTU) & $402 \pm 62$ & $388 \pm 29$ & $395 \pm 44$ & $399 \pm 122$ & $532 \pm 143$ & $466 \pm 140$ & $589.7 \pm 23$ & $550 \pm 89$ & $570 \pm 62$ \\
\hline Fat $\left(\mathrm{mg} \mathrm{l}^{-1}\right)$ & $412 \pm 35$ & $401 \pm 19$ & $407 \pm 26.24$ & $99 \pm 11$ & $108 \pm 13$ & $103 \pm 10$ & $89 \pm 3$ & $107 \pm 33$ & $89 \pm 4$ \\
\hline $\begin{array}{c}\text { TC } \\
\text { (No./100 ml) }\end{array}$ & $10^{9} \times 44$ & $10^{9} \times 42$ & $10^{9} \times 43$ & $10^{11} \times 1.4$ & $10^{11} \times 1.2$ & $10^{11} \times 1.3$ & $10^{9} \times 92$ & $10^{9} \times 90$ & $10^{9} \times 91$ \\
\hline $\begin{array}{c}\mathrm{FC} \\
\text { (No./100 ml) }\end{array}$ & $10^{9} \times 38$ & $10^{9} \times 34$ & $10^{9} \times 36$ & $10^{9} \times 28$ & $10^{9} \times 26$ & $10^{9} \times 27$ & $10^{9} \times 28$ & $10^{9} \times 27$ & $10^{9} \times 27$ \\
\hline
\end{tabular}

Abbreviations: Ave: Average, S.D: Standard deviation 
Slaughterhouse wastewater is characterized in term of its physical, chemical, and biological properties. Physical characteristics such as TSS, turbidity, temperature and conductivity, chemical characteristics such as $\mathrm{pH}, \mathrm{COD}, \mathrm{BOD}_{5}$ and fat and biological characteristics such as TC and FC were evaluated in this study.

The TSS content of Ahvaz wastewater samples ranges from 1,900 to 2,023 $\mathrm{mg} \mathrm{l}^{-1}$ with an average of 1,764 $\mathrm{mg} \mathrm{l}^{-1}$. while this amount in Dezful wastewater samples ranges from 1,782 to $1,921 \mathrm{mg} \mathrm{l}^{-1}$ with an average of $1,864 \mathrm{mg} \mathrm{l}^{-1}$, and in Shushtar wastewater samples ranges from 1,224 to 2,000 $\mathrm{mg} \mathrm{l}^{-1}$ with an average of $1,481 \mathrm{mg} \mathrm{l}^{-1}$. These values are extremely significant because suspended solids can lead to the development of sludge deposits and anaerobic conditions when untreated wastewater is discharged in the aquatic environment.

The temperature is one of the most important factors of wastewater treatment because of chemical reactions, the reaction rate, and the aquatic life. For bacterial activity, the optimum temperature is in the range of 25 to $35^{\circ} \mathrm{C}$ (Metcalf, 2003). In every three slaughterhouses, average temperatures were 21 and 28 in spring and summer, respectively.

Suitable $\mathrm{pH}$ for the existence of biological life is quite narrow and critical and is typically 6 to 9 . In low $\mathrm{pH}$, biological wastewater treatment is difficult and can affect on hydrogen ion concentration of the receiving water. For treated effluent discharge to the environmental the allowable $\mathrm{pH}$ range varies from 6.5 to 8.5 (Metcalf, 2003). In this study, the average raw wastewater pHs in every three slaughterhouses was 6.8, and is within the range favored by the bacteria.

As shown in Table 3, the samples of the studied slaughterhouses have slightly low COD content in the summer season compared to the spring. One reason could be an increase in water consumption in summer leads to dilution of the sample. The COD of Ahvaz raw wastewater ranges from 4,200 to 5,560 $\mathrm{mg} \mathrm{O}_{2} \mathrm{l}^{-1}$ with an average of 4,920 mg O $\mathrm{I}^{-1}$ in spring, while it ranges from 4,300 to 5,200 mg $\mathrm{O}_{2} \mathrm{l}^{-1}$ with an average of $4,783 \mathrm{mg} \mathrm{O}_{2} \mathrm{l}^{-1}$ in summer. Similar trend is presented in Table 3 for the COD content of raw wastewater samples obtained from Dezful and Shushtar. The observed spring COD for the raw samples of Dezful ranges from 4,470 to $5,100 \mathrm{mg} \mathrm{O}_{2} \mathrm{l}^{-1}$ with an average of 4,757 mg $\mathrm{O}_{2} \mathrm{l}^{-1}$ while the summer COD was from 4,320 to 4,610 $\mathrm{mg} \mathrm{O}_{2} \mathrm{l}^{-1}$ with an average of 4,477 $\mathrm{mg} \mathrm{O}_{2} \mathrm{I}^{-1}$.

The most widely used parameter of organic pollution applied to wastewater is the 5 - day biological oxygen demand $\left(\mathrm{BOD}_{5}\right)$. The average amounts of $\mathrm{BOD}_{5}$ were $2,611 \mathrm{mg} \mathrm{O}_{2} \mathrm{l}^{-1}, 1,567 \mathrm{mg} \mathrm{O}_{2} \mathrm{l}^{-1}$ and 1,224 $\mathrm{mg} \mathrm{O}_{2} \mathrm{l}^{-1}$ in raw samples of Ahvaz, Dezful and Shushtar, respectively.

The ratio of $\mathrm{BOD}_{5} / \mathrm{COD}$ for Ahvaz, Dezful and Shushtar raw wastewater were 0.54, 0.34 and 0.32, respectively, which showed a moderate biodegradability. These numbers are comparable to those presented by Metcalf and Eddy, (2003) who stated that the typical values for $\mathrm{BOD}_{5} / \mathrm{COD}$ ratio of untreated municipal wastewater are usually in the range from 0.3 to 0.8 , and indicated that if this ratio is equal 0.5 or greater, the wastewater is considered to be easily treated by biological means. If the ratio is below about 0.3 , either the wastewater may have some toxic components. On this basis, it was determined that the biological treatment is applicable in case of Ahvaz, Dezful and Shushtar slaughterhouses wastewater treatment.

Table 4. Comparison of slaughterhouse wastewater characteristics

\begin{tabular}{ccccccc}
\hline Parameters & $\begin{array}{c}\text { Sarairah } \\
\text { and Jamrah, } \\
\mathbf{2 0 1 0}\end{array}$ & $\begin{array}{c}\text { Massé and } \\
\text { Masse, 2000a }\end{array}$ & $\begin{array}{c}\text { Fuchs et al., } \\
\mathbf{2 0 0 3}\end{array}$ & $\begin{array}{c}\text { Budiyono et al., } \\
\mathbf{2 0 1 1}\end{array}$ & Kobya et al., 2006 & Current study \\
\hline $\mathrm{pH}$ & 6.69 & 6.5 & 6.05 & 7.19 & 6.7 & 6.8 \\
\hline $\mathrm{TSS}\left(\mathrm{mg} \mathrm{l}^{-1}\right)$ & 863 & 1431 & 3,550 & 1171 & 1020 & 1703 \\
\hline $\operatorname{BOD} 5\left(\mathrm{mg} \mathrm{l}^{-1}\right)$ & 1235 & -- & 6,000 & 1873 & 11000 & 1800 \\
\hline $\operatorname{COD}\left(\mathrm{m} \mathrm{l}^{-1}\right)$ & 2144 & 3417 & 12,975 & 3756 & 27500 & 4408 \\
\hline
\end{tabular}

The biological characteristics of wastewater are fundamental importance in the control of diseases caused by pathogenic organisms and because of the extensive role played by bacteria and other organisms in decomposition and stabilization of organic material in wastewater treatment. Total coliform bacteria (TC) and fecal coliform bacteria (FC) were studied as indicators of fecal contamination. The average amounts 
of TC and FC in raw wastewater of mentioned slaughterhouses were about $43 \times 10^{9}$ and $36 \times 10^{9}$ in Ahvaz, $1.1 \times 10^{11}$ and $27 \times 10^{9}$ in Dezful, and $91 \times 10^{9}$ and $27 \times 10^{9}$ in Shushtar.

The measured TSS, COD, TC, FC and etc results indicate that the produced wastewater is classified by pollution severity as a strong wastewater, since reported values for wastewater that is classified as strong (Metcalf, 2003) show values that are lower than those measured.

Previous researches carried out on slaughterhouse wastewater characterization are reported in Table 4, which also compares those findings to the results of present study. This table shown that the results of this study were very well comparable to those stated in the literature. The slight difference between the numbers reported in the table can be related to several factors such as wastewater type, processing, measurements technique, efficiency of blood capturing system, amount of consumed water, production capacity of slaughterhouse, type and weight of animal, methods of transportation, animal receiving and holding, cleaning and sanitizing procedure, labours behavior and other slaughterhouse activities (Budiyono et al., 2011, Sarairah and Jamrah, 2010).
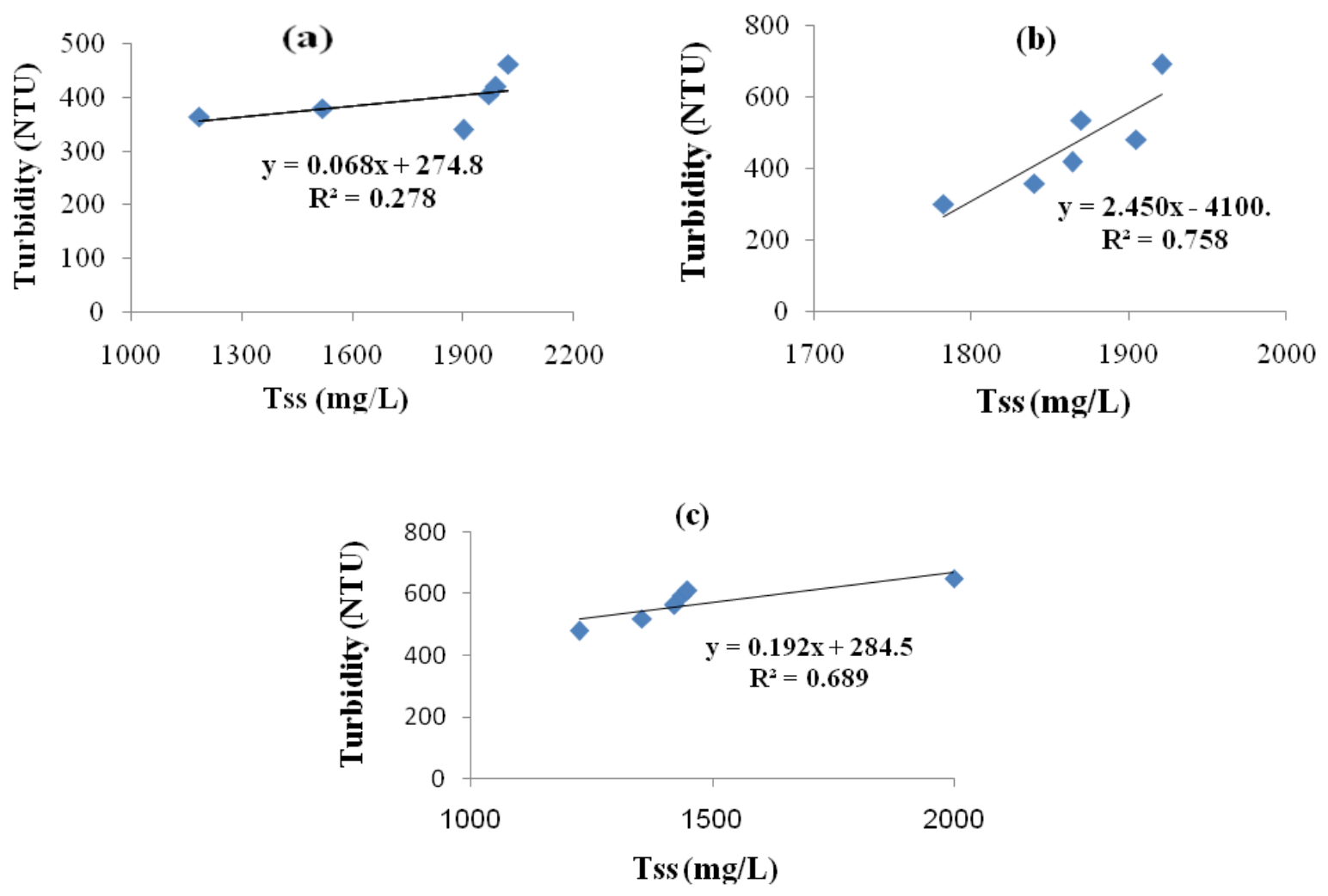

Figure 1. A plot of TSS versus Turbidity contents of raw slaughterhouse wastewater samples:

a) Ahvaz, b) Dezful, c) Shushtar

The various interrelationships prevailing among the different characteristics of slaughterhouse wastewater is shown in Figure 1. It shows regression formula obtained between the turbidity and the TSS content in untreated wastewater samples. This Figure also shows a positive correlation is existed between the parameters as indicated by coefficient of determination $\left(r^{2}\right)$. Indeed, the organic contents of the slaughterhouse wastewater are associated significantly with suspended solids indicates that anaerobic biological treatment could be more efficient for the treatment of this type of wastewater (Metcalf, 2003). Currently, the anaerobic treatment of wastewater is used only in Ahvaz slaughterhouse. 


\subsection{Characteristics of the final effluent}

The average amount of physical, chemical and biological characteristics of the discharged wastewater from each of slaughterhouses and their acceptability for effluent reuse according to the standard of Iran have been shown in the Table 5 . Analyzing the contents of this table indicates that numbers related to $\mathrm{pH}$, Fat and FC of Ahvaz slaughterhouse effluent are acceptable for reuse, while Dezful and Shushtar slaughterhouse effluent just $\mathrm{pH}$ are well within the limits allowing their reuse. Numbers related to TSS, $\mathrm{BOD}_{5}, \mathrm{COD}$, turbidity and TC of effluent in every three slaughterhouse effluent exceed the limits required by the standard of Iran. Also, it was observed that the industrial wastewater of Ahvaz, Dezful and Shushtar slaughterhouse contained blood, fatty particles, meat and other wastes due to the lack of blood discharge units.

Table 5. Quality of the effluent for each studied SWWTP and acceptability for effluent reuse according to the standard of Iran

\begin{tabular}{|c|c|c|c|c|c|c|}
\hline \multirow[b]{2}{*}{ Parameters } & \multicolumn{2}{|c|}{ Ahvaz } & \multicolumn{2}{|c|}{ Dezful } & \multicolumn{2}{|c|}{ Shushtar } \\
\hline & Ave \pm S.D. & $\begin{array}{c}\text { Acceptability for } \\
\text { reuse }\end{array}$ & Ave \pm S.D. & $\begin{array}{c}\text { Acceptability } \\
\text { for reuse }\end{array}$ & Ave \pm S.D. & $\begin{array}{c}\text { Acceptability } \\
\text { for reuse }\end{array}$ \\
\hline $\mathrm{pH}$ & $8 \pm 0.3$ & Yes & $6.4 \pm 0.3$ & Yes & $6.9 \pm 0.9$ & Yes \\
\hline TSS (mg l-1) & $254 \pm 27$ & No & $1117 \pm 39.7$ & No & $1481 \pm 244$ & No \\
\hline $\mathrm{BOD}_{5}\left(\mathrm{mg} \mathrm{l}^{-1}\right)$ & $129 \pm 25.6$ & No & $1270 \pm 115.5$ & No & $1224 \pm 185$ & No \\
\hline $\operatorname{COD}\left(\mathrm{mg} \mathrm{l}^{-1}\right)$ & $325 \pm 66.3$ & No & $3640 \pm 215.8$ & No & $3823 \pm 452$ & No \\
\hline $\begin{array}{l}\text { Turbidity } \\
\text { (NTU) }\end{array}$ & $90 \pm 5.7$ & No & $372 \pm 111.4$ & No & $570 \pm 62$ & No \\
\hline Fat $\left(\mathrm{mg} \mathrm{l}^{-1}\right)$ & $2 \pm 0.5$ & Yes & $83 \pm 8.2$ & No & $89 \pm 4$ & No \\
\hline $\begin{array}{c}\mathrm{TC} \\
\text { (No./100 mL) } \\
\end{array}$ & 1100 & No & $10^{11} \times 0.69$ & No & $10^{9} \times 91$ & No \\
\hline $\begin{array}{c}\text { FC } \\
\text { (No./100 mL) }\end{array}$ & 220 & Yes & $10^{8} \times 4.72$ & No & $10^{9} \times 27$ & No \\
\hline
\end{tabular}

\subsection{Removal efficiencies of pollutants for each WWTP}

Table 6 showed the removal efficiencies of TSS, $\mathrm{BOD}_{5}, \mathrm{COD}$, turbidity, TC, and FC for each WWTP. In Ahvaz slaughterhouse, it is found the effluent has been used for the irrigation of green spaces and in other seasons it is drained into the Karoon River. The average removal efficiencies of pollutants in Ahvaz WWTP, which was based on the results listed in Table 6, were: $87 \%$ TSS, $94.4 \% \mathrm{BOD}_{5}$, and $93 \% \mathrm{COD}, 78 \%$ turbidity. Fat and coliform bacteria removal efficiencies also were estimated to be $99.9 \%$. Thus, according to Table 6, WWTP of Ahvaz has the highest removal efficiencies of $\mathrm{COD}, \mathrm{BOD}_{5}$, TSS and etc. The means of the pair samples also indicated the positive effect of this system on decreasing the TSS, COD, BOD 5 , fat, TC, and FC ( $\left.p_{\text {value }}<0.05\right)$.

Table 6. Pollutants removal efficiency of each SWWTP (\%)

\begin{tabular}{cccccccc}
\hline Slaughterhouse & TSS & BOD $_{5}$ & COD & Turbidity & Fat & TC & FC \\
\hline Ahvaz & 87 & 94.4 & 93 & 78 & 99.9 & 99.9 & 99.9 \\
\hline Dezful & 40 & 19 & 20 & 20 & 20 & 35 & 35 \\
\hline
\end{tabular}

On the base of available evidence, stabilization ponds with better performance can remove $70-80 \% \mathrm{BOD}_{5}$ from the unfiltered samples. This capability will increase to $97 \%$ for filtered samples with a reduction of $96 \%$ of COD and $95 \%$ for TSS. Farzadkia et al., (2005) reported that these ponds can remove COD, BOD 5 and TSS up to $75.1 \%, 87.4 \%$ and $89.4 \%$ respectively. They also stated that application of the extended aeration activated Sludge process for slaughterhouse wastewater treatment can remove the $\mathrm{BOD}_{5}$ up to $90-95 \%$. The comparison of contaminants removal percent in anaerobic stabilization ponds and extended aeration process of the Ahvaz slaughterhouse with mentioned standards in Table 1 confirmed that the efficiency of this process is relatively desired.

Al-Mutairi et al., (2003) also indicated contact stabilization activated sludge process effectively reduces pollution potential of slaughterhouse wastewater generated in Kuwait city. Their results shown the COD 
of slaughterhouse wastewater ranged from 3,335 to $7,580 \mathrm{mg} \mathrm{l}^{-1}$, of which approximately $30 \%$ was in the form of SS. removal efficiency of mentioned process was $77 \%$ for soluble COD and $82 \%$ for insoluble COD when the applied volumetric loading rate was $1.8 \mathrm{~kg} \mathrm{COD} \mathrm{m}^{-3}$.

Else, in Dezful slaughterhouse, the effluent of the septic tank has been used to irrigate the surrounding lands in agricultural season and in other seasons; it is discharged into the Dez River. The results indicated the positive effect of the septic tank system on decreasing the TSS, COD, BOD 5 , fat, and turbidity $\left(P_{\text {value }}<0.05\right)$. Based on the results of the Table 6, average removal efficiencies of pollutants were: $40 \%$ TSS, $19 \% \mathrm{BOD}_{5}, 20 \% \mathrm{COD}$, fat and turbidity, and 35\% coliform bacteria. Similar results have also been reported in Kupusovic et al., (2007) study on cleaner production measures in small-scale slaughterhouse industry-case study in Bosnia and Herzegovina, aimed to reduce waste and improved the efficacy of septic tank unit. They reported that the septic tanks do not function properly so the quality of wastewater has not improved significantly. The reason for this may be poor design or construction of the septic tanks. Another reason could be due to the very high organic loading. This problem will be eliminated by the installment of equipment for the separation of blood and its proper management. It is to be noted that the efficacy of septic tank for wastewater treatment was about 40 to $50 \%$ in best operating conditions. Then, septic tank units are considered as wastewater pretreatment.

Also, it is found that Shushtar slaughterhouse industry discharges all its wastewater, without any treatment process, into the Gorger River. Consuming too much water results in excessive wastewater production per livestock slaughtered in the Shushtar slaughterhouse and leads to the dilution of wastewater in this slaughterhouse. In a way that the quality of the raw wastewater is almost equivalent to the effluent quality of the septic tank (Dezful). Although this matter about the quality of produced wastewater and its treatment is considered to be a positive thing, but overall due to the large amounts of wastewater produced, it is considered to be a negative and undesirable factor. Lack of WWTP and drainage of raw wastewater is the basic problem in most of the slaughterhouse centers.

\subsection{Comparison of the final effluent quality with the Iran EPA standard}

In Figures 2 and 3 , the average values of $\mathrm{COD}, \mathrm{BOD}_{5}, \mathrm{TSS}, \mathrm{TC}$ and $\mathrm{FC}$ for each WWTP were compared with the standards of Iran EPA.

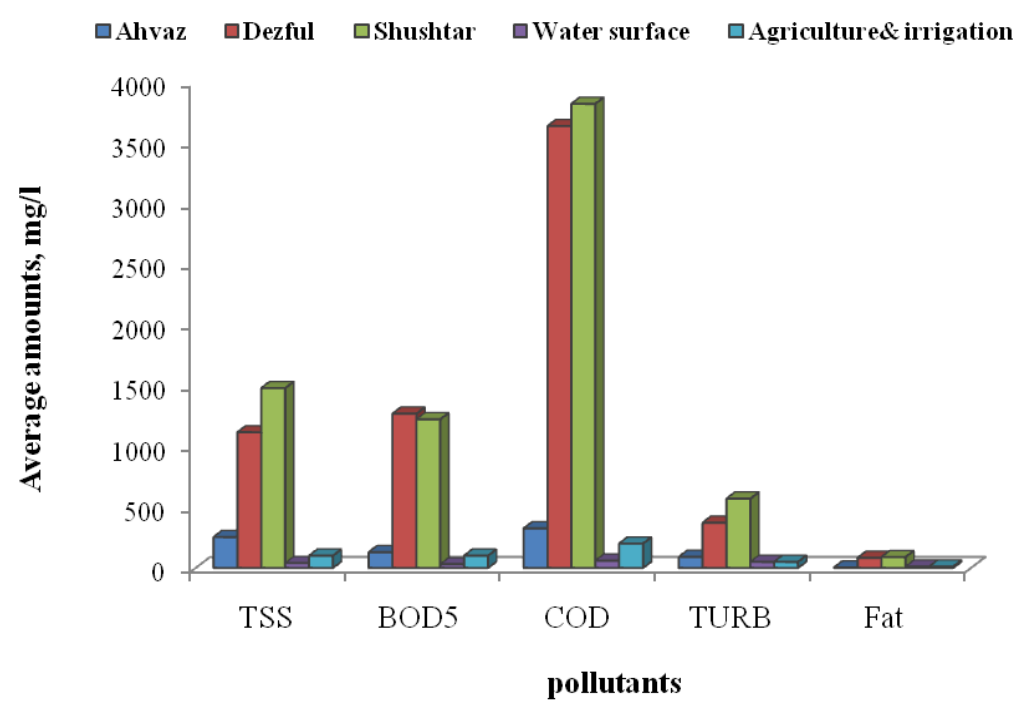

Figure 2. Comparison of the average value of effluent $\mathrm{COD}, \mathrm{BOD}_{5}$, and TSS with the standards of Iran

Analysis of obtained data shows that the effluent of Ahvaz WWTP provides both standards of $\mathrm{pH}$, oil and grease, and fecal coliform. However, this wastewater does not provide the above standards for COD, $\mathrm{BOD}_{5}$, TSS, turbidity, and total coliform. 
These results indicate a relatively good treatment. But as the load of the input contaminants was very high, in most cases the concentration of produced wastewater was more than the Iran EPA limits. The unsatisfactory performance of the WWTP can be primarily due to the lack of separation of blood and stomach contents of the slaughtered livestock. However, observations and field studies showed that the lack of good governance of treatment units such as anaerobic pond and activated sludge also have a role in reducing the efficiency. These Factors also were reported in Farzadkia et al., (2005) survey on the wastewater stabilization efficiency in treating Kermanshah slaughter wastewater.

In Dezful slaughterhouse we found all of the pollutants, except $\mathrm{pH}$, in septic tank effluent did not meet the standards of Iran EPA for reuse in irrigating the agricultural lands or its disposal to the surface waters. Also, it is found that in Shushtar slaughterhouse, total contaminations of wastewater were several times more than the standards of Iran EPA.

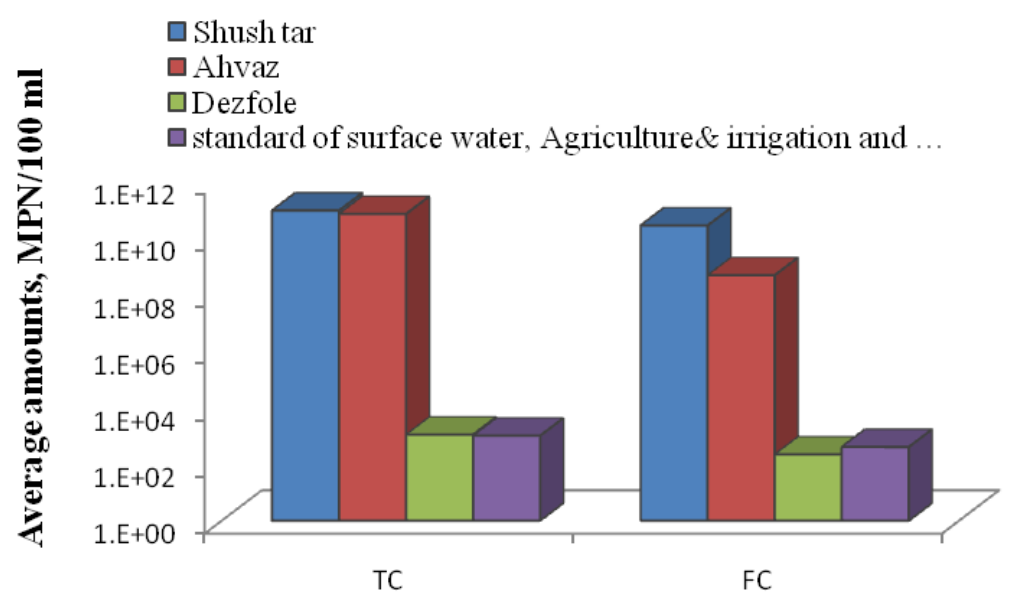

Biological pollutants (No./100ml)

Figure 3. Comparison of the average value of effluent TC and FC with the standard of Iran

\subsection{Operation Modifications and Short guide to improve SWWTP efficiency}

In general, the slaughterhouses of Ahvaz, Dezful and Shushtar could not provide the Iran EPA standards to effluent reuse for agricultural or effluent disposal to the surface waters. If the reuse of effluent or also effluent sanitary disposal, the following cases need to be considered for the slaughterhouse. So, in the Ahvaz WWTP, installation of equipment for the separation of blood and gastric contents, multi staged application of trash from coarse to fine, equipment for trapping the fats and foaming water at the pond outlet, and preventing entry of this substance into the activated sludge units, using an expert and professional operator, planning regular visits for action of the pond, aeration, sedimentation and chlorination basins, periodic evaluation of the system including the control of the input and output wastewater loading, activated sludge systems, continuous sanitary drainage of waste and excess sludge of the units are recommended.

The efficiency of the septic tank showed partial treatment of the wastewater in Dezful slaughterhouse. This unit requires installation of emergency equipment for separation of blood and gastric contents. Planning and management of input wastewater loads to the septic tank, quality evaluation of effluent, periodic disposal of the sludge, fats, and foaming water should be reviewed and amended. Finally, in a short time a complete WWTP should be constructed and wastewater treatment projects should be completed in this unit.

Presence of the Shushtar slaughterhouse near urban housing and its proximity to the Gorger River on one hand, old and primitive buildings on the other side, equipping this slaughterhouse to WWTP is not economically and logically feasible. On this basis, a new semi industrial slaughterhouse at $7 \mathrm{~km}$ from the city of Shushtar, $5 \mathrm{~km}$ from the village Golal, in accordance with the environmental standards established by the municipality, this project should be operational soon with the authenticity and more facilities. 


\section{Conclusion}

Given none of the studied slaughterhouses can reach the desirable level of standards, to improve the quality of slaughterhouse wastewater and use it for agriculture purposes following items are suggested: minimizing and recycling byproducts, separation and collection of blood and gastric contents from raw wastewater and use in industry such as pharmaceutical industry, collecting fat from raw wastewater and using them in Soap industry, biological and chemical treatment of slaughterhouse wastewater.

Finally, the slaughterhouses are normally controlled by local bodies, which should follow the standards prescribed, but due to non-existence of modernized slaughterhouses, environmental pollution arising out of the slaughtering activities cannot be controlled. It is suggested that the local bodies take up modernization of slaughterhouses and achieve the pollution control norms.

\section{Acknowledgment}

This study was funded by Iran University of Medical Sciences, Department of Environmental Health Engineering. The authors would like to thank the laboratory staff of the department for their collaboration in this research.

\section{References}

Aguilar M., Saez J., Llorens M., Soler A. and Ortuno J. (2003), Microscopic observation of particle reduction in slaughterhouse wastewater by coagulation-flocculation using ferric sulphate as coagulant and different coagulant aids, Water Research, 37, 2233-2241.

Al-Mutairi N.Z., Hamoda M.F. and Al-Ghusain I.A. (2003), Performance-based characterization of a contact stabilization process for slaughterhouse wastewater, Journal of Environmental Science and Health, Part A, 38, 2287-2300.

APHA (1992), Standard Methods for the Examination of Water and Wastewater, Washington, DC: American Public Health Association.

Bazrafshan E., Mostafapour F.K., Farzadkia M., Ownagh K.A. and Mahvi A.H. (2012), Slaughterhouse wastewater treatment by combined chemical coagulation and electrocoagulation process. PloS one, 7, e40108.

Budiyono B., Seno J. and Sunarso S. (2011), Study on slaughterhouse wastes potency and characteristic for biogas production, International Journal of Waste Resources, (IJWR), 1.

Caixeta C.E., Cammarota M.C. and Xavier A.M. (2002), Slaughterhouse wastewater treatment: evaluation of a new three-phase separation system in a UASB reactor, Bioresource Technology, 81, 61-69.

Del Nery V., Damianovic M. and Barros F. (2001), The use of upflow anaerobic sludge blanket reactors in the treatment of poultry slaughterhouse wastewater, Water Science and Technology, 44, 83-88.

Del Pozo R. and Diez V. (2005), Integrated anaerobic-aerobic fixed-film reactor for slaughterhouse wastewater treatment, Water Research, 39, 1114-1122.

Farzadkia M. (2005), Application of High Rate Stabilization Ponds for Treatment of Kermanshah City Slaughterhouse, Journal of Water \& Wastewater, 10-16.

Fuchs W., Binder H., Mavrias G. and Braun R. (2003), Anaerobic treatment of wastewater with high organic content using a stirred tank reactor coupled with a membrane filtration unit, Water Research, 37, 902-908.

Gurel L. and Buyukgungor H. (2011), Treatment of slaughterhouse plant wastewater by using a membrane bioreactor, Water Science and Technology, 64, 214-219.

Kobya M., Senturk E. and Bayramoglu M. (2006), Treatment of poultry slaughterhouse wastewaters by electrocoagulation, Journal of hazardous materials, 133, 172-176.

Kupusovic T., Midzic S., Silajdzic I. and Bjelavac J. (2007), Cleaner production measures in small-scale slaughterhouse industry-case study in Bosnia and Herzegovina, Journal of Cleaner Production, 15, 378-383.

Manjunath N., Mehrotra I. and Mathur R. (2000), Treatment of wastewater from slaughterhouse by DAF-UASB system, Water Research, 34, 1930-1936. 
Masse D. and Masse L. (2000), Characterization of wastewater from hog slaughterhouses in Eastern Canada and evaluation of their in-plant wastewater treatment systems, Canadian Agricultural Engineering, 42, 139-146.

Masse D.I. and Masse L. (2001), The effect of temperature on slaughterhouse wastewater treatment in anaerobic sequencing batch reactors, Bioresource Technology, 76, 91-98.

Masse L. and Masse D. (2005), Effect of soluble organic, particulate organic, and hydraulic shock loads on anaerobic sequencing batch reactors treating slaughterhouse wastewater at $20 \mathrm{C}$. Process Biochemistry, 40, 1225-1232.

Metcalf E. 2003. Inc., Wastewater Engineering, Treatment and Reuse. New York: McGraw-Hill.

Nafarnda W., Ajayi I., Shawulu J., Kawe M., Omeiza G., Sani N., Tenuche O. and Dantong D. (2012), Bacteriological Quality of Abattoir Effluents Discharged into Water Bodies in Abuja, Nigeria, International Scholarly Research Notices, doi: 10.5402/2012/515689

Saddoud A. and Sayadi S. (2007), Application of acidogenic fixed-bed reactor prior to anaerobic membrane bioreactor for sustainable slaughterhouse wastewater treatment, Journal of Hazardous Materials, 149, 700-706.

Sarairah A. and Jamrah A. (2010), Characterization and assessment of treatability of wastewater generated in Amman slaughterhouse, Dirasat: Engineering Sciences, 35, 71-83.

Ün Ü.T., Koparal A.S. and Öğutveren Ü.B. (2009), Hybrid processes for the treatment of cattle-slaughterhouse wastewater using aluminum and iron electrodes, Journal of Hazardous Materials, 164, 580-586. 